\title{
ENCOURAGING THE GROWTH OF SKILLS AND INNOVATION IN THE NETHERLANDS
}

Prof. dr. sc. Frans Pennings*

\author{
UDK: $331.522 .4(492)$ \\ https://doi.org/10.30925/zpfsr.39.4.18 \\ Ur.: 14. svibnja 2018. \\ Pr.: 5. rujna 2018. \\ Osvrt
}

\section{Summary}

This paper describes an example of best practice in the Netherlands with respect to promoting the innovation of enterprises. This policy consists of promoting cooperation between knowledge centres (including universities) and enterprises, enabling the enterprises and start-ups to be located in the neighbourhood of knowledge centres and assisting them in obtaining the required permits, and, if necessary, grant subsidies. This policy has proved to be very successful. Developing a training policy for all sectors of economy, on the other hand, is more difficult. This becomes even more difficult if employers and employees have opposite interests, especially if employers fear that the newly trained worker will leave their job after acquiring the new qualification or if the worker has to reimburse the subsidy. Therefore, the establishment of training funds, made available for all employers and workers who want to qualify for another job, can contribute to the growth of skills.

Keywords: innovations; the Netherlands; training policy; growth of skills; workers.

\section{INTRODUCTION}

Encouraging the growth of skills and innovation is not an easy task, since creativity and innovation are primarily bottom-up processes. Individuals and enterprises are the ones that have to find the areas and methods for new products, ideas or production processes.

Still, the government and social partners can have a stimulating role in this regard, mainly by creating a framework and climate that is beneficial for innovation.

* Frans Pennings, Ph.D., Full Professor, Faculty of Law, Utrecht University, the Netherlands; f.pennings@uu.nl.

This work has been supported in part by the Croatian Science Foundation - Project UIP-201409-9377 "Flexicurity and New Forms of Employment (Challenges regarding Modernization of Croatian Labour Law)". 
This paper depicts the way in which the Netherlands has stimulated innovation in the past decade. It is a process that is not perfect and can still be improved, but the experiences in this country may serve as a best practice example.

The paper first describes some good practices of how innovation is stimulated and the role of public authorities in this stimulation (section 2). Section 3, on the other hand, deals with the organisation of the labour market.

\section{ENCOURAGING INNOVATION BY CREATING INNOVATIVE NETWORK AREAS}

First of all, it needs to be pointed out that the government has since the 1980s not been subsidizing declining industries. The reason was that at the time there were some bad experiences, when ship manufacturers or airplane factories (Fokker) received very large subsidies, but still did not survive. As a result, the Netherlands lost important industries, including car and airplane manufacturing, shipbuilding and textile. These restructurings of large economic sectors were, of course, very painful as they resulted in many people suffering from job losses. Based on these experiences, it was concluded that supporting declining industries costs large amounts of money, which will never save those industries. Instead, a good safety net, in the form of unemployment benefit schemes, provided for an income for the redundant workers.

Nowadays such subsidizing may also cause problems under the EU State aid rules, but the Netherlands realized already the pitfalls of subsidizing declining industries long before such rules began to have impact. Another instrument to soften the effects of the crisis was introduced during the economic crisis of 2008 was a short-term scheme that enabled firms to keep workers employed, since, if they are dismissed and later new workers have to be recruited, a lot of valuable expertise could be lost. But apart from these examples, in such temporary crises no subsidy scheme is available.

For some industries that were outsourced to low-wage countries (such as textile), the Netherlands has developed new technologies for making high tech materials or more sustainable production processes, e.g. more sustainable or lighter clothes, carpets or curtains, or fireproof or waterproof materials. Therefore, we can claim that in fact we witness here a shift from mass production to innovation in the sense of high-tech creativity.

Such innovations depend on the creativity of persons or groups of persons and cannot be organized in economies based on central planning.

However, in the past decades there have been interesting experiences supporting innovation.

One of the brightest examples is that of Eindhoven, a city in the south of the Netherlands. It all started after the bankruptcy of DAF, an automobile manufacturer, and the reorganisation of the Philips company in the 1990s, when many jobs were lost and the region was on the verge of collapse and there was a fear of mass unemployment.

The former mayor of Eindhoven, the president of the board of Eindhoven University and the president of the Chamber of Commerce organized a cooperation of 
public authorities, research institutions and enterprises, and attracted investments to Eindhoven. This led to the establishment of the Brainport Foundation, an organisation that continues to stimulate cooperation and facilitates transition from a declining industry and mass unemployment to an international high-tech centre in a global network.

As a result, Brainport has become a top technology region supporting innovation, in which the regional authorities support cooperation of the large Philips company, the Eindhoven technical University and start-ups. ${ }^{1}$ Thus campuses for the development of transport devices were created, where state of the art technological (testing) facilities and flexible housing concepts are provided. Enterprises, education and research institutions are thus located together and their cooperation is encouraged.

This transition from a manufacturing industry to a network of research and knowledge is a clear example of how innovation can take place and help declining regions to survive. It also shows that it were the public authorities that took the initiative to encourage the network of the relevant stakeholders and that a combination of research institutions (universities) and enterprises is a fruitful one.

In order to stimulate the cooperation of these stakeholders, innovative enterprises are situated close to each other, for instance on the university campus or at the technical university. Sometimes they are placed in a special building containing a considerable number of innovative enterprises. Innovation can further be promoted by facilitating the process of obtaining the permits for production, extension of the building, etc.

This approach is now also followed in other cities, where a campus or science park is designated for innovative enterprises and institutions, such as food technology and mobility solutions. A great number of researchers, developers and entrepreneurs work in hundreds of companies and institutions to develop new products on this campus and such cooperation indeed creates synergy and has an added value.

Furthermore, Dutch universities have taken the initiative to develop science parks, which allow enterprises to be in the vicinity of both each other and the creative institute. Such concentrated area of innovative enterprises allows, for instance, also researchers of the university and students and graduates of the university to try out and develop products. Such cooperation can become a start-up and later even be a company making profits. ${ }^{2}$ Important challenges for these innovative areas are to create more sustainable products, to reduce waste and consumption of energy or to develop an efficient agriculture. All these questions require intensive and creative research.

This is, of course, not the only way to promote innovation, but a very successful one.

These examples, however, cannot be simply copied. Still, the idea of connecting research institutions and companies and allowing new companies to develop in the vicinity of these institutions and encourage cross-fertilisation is not unique.

The second way in which innovation can be promoted by the government is

1 Called Brainport, www.brainport.nl.

2 Some multinationals like Unilever decided recently to move their research and development centre to such a campus, https://www.unilever.nl/news/persberichten/2016/unilever-intendsto-build-a-global-foods-innovation-centre-in-wageningen-the-netherlands.html. 
by linking applied research institutions to companies, in particular to the small and middle-size companies. After all, large companies often already have their own research units, but the smaller ones have more difficulties with accessing research.

Research institutions are therefore encouraged and subsidised in order to help companies innovating their products or production processes; small and mediumsized companies can also be encouraged to develop products based on the findings of technological institutions.

A recent report suggests that research institutions are often too expensive for small and medium-sized enterprises; ${ }^{3}$ the report proposed to the government to adopt a financial scheme which would make it more attractive for small and medium-sized companies to cooperate with technological institutions. The institutions should also become more proactive in order for them to be able to identify in which way they can support innovative activities in small and medium-sized companies.

The report also advises the technological institutions to connect with other innovative institutions, such as the innovative campus we discussed above. The commission added that the government has a role in this: it should clearly define the innovation and knowledge agenda for institutions (and facilitate this by sufficient means) so that the institutions can respond to developing needs of society.

\section{THE ORGANIZATION OF LABOUR MARKET AND ENCOURAGING INNOVATION AND THE GROWTH OF SKILLS}

\subsection{A general policy for life-long learning?}

The starting point in the skills and qualification policy is that young persons should acquire the so-called basic qualification, i.e. a diploma of secondary education. If a person does not have such basic qualification and leaves school, s/he does not qualify for social assistance.

It is a challenge to make education attractive also for pupils who do not like to study; having a good combination of practical work and theory in school is one of the approaches that might improve the situation. This is important since improving skills is most often possible only if persons have a basic qualification.

About 7 years ago a provision was inserted into the Civil Code (Article3 7:611a $\mathrm{BW}$ ), that obliges employers to allow employees attend training that is necessary for performing their job and, as far as can reasonably be asked from the employer, for the continuation of the contract of employment if the function of the employee is cancelled or when he will no longer be able to perform his work. In theory, the employee can also be asked to participate in the training, since s/he has the statutory obligation to behave as a good employee, which sometimes might entail training.

However, forcing a person to attend training that $\mathrm{s} / \mathrm{he}$ does not want to is often not very fruitful.

Therefore, it is more relevant whether there are instruments to make the attendance of training attractive so that it becomes part of one's working career.

3 Commissie Schaaf, Evaluatieonderzoek organisaties voor toegepast onderzoek (TO2), 2017. 
There is still no general all-encompassing training policy in the Netherlands. Attempts have been made by social partners, i.e. employers' and employees' organisations, to agree in collective agreements on the establishment of training funds. Employers contribute to these funds and enterprises can receive a contribution for training employees from the fund.

However, training has not yet been included in the structure of working life.

Based on recent figures of the Sociaal-Cultureel Planbureau ${ }^{4}$ (an agency studying developments in society) it appeared that $24 \%$ of the employers are of the view that employees should attend work-related training and courses as far as possible outside their working hours-. About one-third of the employers (36\%) argue that employees must decide themselves whether they need courses or training.

From this we can conclude that employers are often not eager to allow workers to attend training and workers are not always interested in attending training, certainly not in their spare time. Employers fear that a worker will leave the job after s/he receives a new qualification, which would mean that the employer concerned has in fact invested in this employee for the benefit of another employer.

The training funds established by collective agreements are not generous enough to solve this problem. Employers often require reimbursement of study costs from the employee if the worker leaves the firm within a certain period. This may discourage employees to attend training.

The figures of the Sociaal-cultureel planbureau suggest that in 2016 in about twenty per cent of the organisations one or more employees requested a study leave, which means that this ambition to study is present in a rather small part of the economy. In these companies employers usually allow their employees to study either fully or partially. The possibilities for such study leave vary depending on the sector. Circa ninety per cent of the organisations in public and educational sectors offer these possibilities; in the transport and other service sectors the percentage is smaller (circa sixty-five per cent). There are also important differences in the share of workers that make use of training: in the sectors of industry, construction, trade and cafés/hotels/ restaurants the employees asked for a study leave only in about twelve percent of the organisations. In the public sector (sixty-three per cent) and education (fifty per cent) this occurred more often. It also seems that $\mathrm{n}$ larger organisations employees tend to use this opportunity more frequently than in the smaller ones.

One-third of the organisations offering training for their employees make use of subsidy schemes, hence, part of their training costs is reimbursed. Larger organisations, however, tend to use these subsidies more often than the smaller ones.

Seventeen per cent of the companies make use of training funds, such as the ones established by collective employment agreements, in particular in the construction sector and industry. Public funds (ten per cent) and fiscal measures (five per cent) are also used for funding training.

Therefore, we can conclude that there are training and education opportunities, but they are used mostly by the employees in large organisations. Moreover, the training opportunities are unevenly distributed over the sectors, hence, in some sectors

4 https://digitaal.scp.nl/arbeidsmarktinkaart-werkgevers2017/scholing-van-werknemers 
the training possibilities are rather low. It seems that subsidies and funds, although helpful, do not always represent a decisive factor, since a considerable number of enterprises do not make use of them.

Given the need for employable and flexible workers, the situation is not satisfactory. Indeed, as we have seen in section 2 of this paper, there are some very innovative sectors in the Netherlands, but there are also many areas where employees should undergo training in order to keep up with the new developments.

\subsection{A policy to put more pressure on employers to support lifelong learning}

It can happen that persons have been doing the same work for a long time and have not (really) developed their skills; as a result, their labour market position can have deteriorated, which can be very problematic when they lose their job and thus encounter difficulties with finding a new one. Therefore, the passivity in this area which is reflected in the unemployment figures, might represent another perspective from which to look at the issue of innovation and promoting the acquisition of new skills.

Several proposals have been made to make employers more responsible for maintaining employability of their workers. For instance, in the report Naar een toekomst die werkt, (Towards a future that works) it was proposed that all employees acquire an individual 'work budget', to which the employer pays contributions, but which can also be improved through additional means. The budget can be used to train the employee concerned and thus help him or her maintain his or her 'employability'. This budget can also be used to finance training or work experience during the transitional period, i.e. the period when an employee has been given notice and has to look for another job. During this period he or she can, without having to work, attend training or traineeship in order to prepare himself or herself for a new job. In such ideal situation a person can easily transfer from one job to another.

However, the proposal was not adopted. The new Dismissal Act (Wet werk en zekerheid), which was adopted in 2015, only faintly reflects the proposal of the report. According to the new rules the worker receives the so-called transitional payment in case of dismissal, which is basically a dismissal payment. However, the employer can deduct the costs spent on the training of this employee for the purpose of finding another job .

Since the law was implemented only recently, we do not know yet what the effects of these rules are and whether and how the rules work out in practice.

The Government has also recently proposed to allow the employer to deduct the expenses for his/her own training from the transitional payment. It is not known yet what the effects of this will be. Therefore, a dilemma arises whether such proposal will make training more attractive and for whom. The possibility of deducting the costs will encourage the employer to organize training, but it will discourage the employee to attend it considering the lower dismissal payment. 


\subsection{Promoting flexibility for the purpose of adapting to innovation}

Innovative firms (such as start-ups) often need a certain degree of flexibility if they employ workers. After all, they do not know whether their enterprise or idea will become successful.

The Netherlands does not exempt particular firms, such as highly innovative firms, from the obligations imposed by labour law. As a matter of fact, there are no special rules in labour law with respect to innovation. As a result, enterprises have to seek a solution within the framework of the existing labour law rules.

In the Netherlands the relation between permanent and fixed-term employment contracts is very heatedly debated.

Permanent contracts provide good protection against dismissal, since the employer has to ask for permission from the competent body, hence, the Uitvoeringsinstituut werknemersverzekeringen (Administration of employees insurance schemes), in order to give notice. For this purpose, the employer must have a file with all the relevant information on the state of affairs and prospects of the company. For this reason, it is more convenient for the employer to conclude fixed-term contracts if he/she is uncertain about his/her permanent need for workers.

The government, however, wants to reduce the number of persons who have a fixed-term contract, since the position of persons who work for a long time based on a series of such contracts is not attractive: these workers are not certain of their future and thus cannot easily buy a house and settle; employers will not invest in their development.

For this purpose the rules on the extension of contracts for a definite period were modified in 2015 by the Wet werk en zekerheid (Act on work and security). Before this modification it was possible to renew a contract three times before it became a contract for an indefinite period; alternatively, it was possible to extend a contract unless the total length exceeded 36 months. As a result, persons could have remained in an uncertain position for a long time. The new rules stipulate that contracts can be extended only twice (instead of three times); moreover, the extension period cannot exceed 24 months (instead of 36 months), otherwise it ex lege becomes a contract for an indefinite period.

The idea behind this new law is that workers are given a contract for an indefinite period sooner. Still, one can increase the extension period through collective agreements, although these possibilities, which were unlimited under the old rules, are now restricted. It now stipulates that the period of 24 months can be extended to 48 months and that the number of concluded fixed-term contracts may amount to six if the intrinsic nature of the work requires such extension.

This new law makes it more difficult to recruit persons on a temporary basis, unless it could be argued that the innovative character of the work intrinsically requires the possibility of having workers on a fixed term contract. This is possible to arrange only though a collective agreement, thus calling for the approval of both the trade unions and the employers in the sector concerned. Naturally, this represents an uncertain and difficult path.

The newest development (2018) proposes to return to the old rules, thus 
reopening the possibility of the chain of three employment contracts or increasing the extension period to more than three years.

An alternative for persons working on a flexible employment contract is hiring them as self-employed, with the latter option increasing considerably in the past ten years. Making use of these workers has important advantages for employers, since the Dismissal Act does not apply to them and in case of sickness employers do not have to continue to pay them. Social security contributions do not have to be paid for them either, since these contributions are due for employees only. For workers it may (seem to) be attractive to work as self-employed since they have a considerably higher net income than the employees, whose social security contributions are deducted from their wage. Of course, recruiting self-employed persons to do work in an organization, where their work closely resembles the one performed by employees, is risky for the employer, since it may happen that the tax authority will consider the person as a worker and then still claim contributions retroactively. On the other hand, this enables start-ups, in which each of the participants works as a self-employed person and has the real status of a self-employed, i.e. with their own responsibilities, to share management and profit.

A change that was also made in 2015 is that the non-competition clause is no longer allowed in a fixed-term contract, unless it appears from the arguments given by the employer in writing that the clause is necessary due to the increasing interests of the company. It remains unclear how this will be reflected in practice, but in any case the judge can test the arguments given by the employer and the burden of proof remains with the employer.

The idea behind this new rule is that the non-competition clause is no longer regarded as justified if a person is given a contract for a definite period only. Although it does not explicitly promote innovation, it is sometimes claimed that competition clauses hinder innovation and that a change in the existing legislation can therefore contribute to innovation. However, since this applies only to short-term contracts, it is unlikely that this change will have any (measurable) effect.

Although the government prefers that the first fixed-term contract does not last too long and that, if a longer employment relationship is necessary, this be realized through the contract for a permanent period, the rules don't prohibit a long-term contract and some companies now experiment with contracts for a five-year period. ${ }^{5}$ The training component is closely related to this, since it should help the employee to find a job elsewhere after this period. This will, naturally, be further regulated in the collective agreement of the company concerned.

Such a contract still creates a long period of uncertainty, as the worker is not given a permanent position, and the contract could thus be seen as contrary to the objectives of the Act. However, the fact that a company undertakes many innovative activities and is thus uncertain about how many workers and which expertise it needs, will be very relevant and challenged by the court.

Whether such long fixed-term contracts are socially and morally acceptable depends to a large extent on the question whether the training and employability

5 For instance the supermarket company Ahold and KLM. 
measures are actually taken.

Another issue related to flexibility is whether an employee can be asked to do different work than s/he used to do or at different locations and times. Countries can have quite different systems in this regard. In the Netherlands, for instance, an employee can, on the basis of the good employee standard laid down in the Civil Code, be asked to be flexible when the work requires. However, the employer also must behave as a good employer. This means that, at the end of the day, it is a matter of negotiation. If an employee has good reasons against the change or if $\mathrm{s} / \mathrm{he}$ offers a good alternative, the employer has to take these into account. This creates a situation in which workers are quite flexible to adjust to a new set of circumstances. In this paper the opinion is represented that major problems in not taking this path lie in the lack of skills to do the new job.

\section{CONCLUSIONS}

Promoting innovation and the growth of skills is an issue that is not easy to organize and for which to make a long-term planning.

The Netherlands ranks quite high among the countries with a good innovation climate, but this can very much be attributed to institutions and areas aimed at and organized for the purpose of innovation. The cross-fertilization areas discussed in this paper can be very helpful in this regard. It is remarkable that public authorities have an important role in stimulating and facilitating these initiatives for co-operation.

Nevertheless, it is difficult to adopt a training policy for all sectors of the economy. Encouraging employers, facilitating training by funds and subsidies, and creating a climate in which it is normal for employees to participate in the training can help, but it cannot automatically create to a general training climate.

When employers and employees have opposite interests this becomes even more difficult, especially if employers fear that the newly trained worker will leave them after acquiring the new qualification or if the worker has to reimburse the subsidy. Therefore, the establishment of training funds, made available for all employers and workers who want to requalify for another job, can contribute to the growth of skills. 


\section{Frans Pennings*}

Sažetak

\section{POTICANJE RAZVIJANJA VJEŠTINA I INOVACIJA U NIZOZEMSKOJ}

Autor u radu prikazuje poduzetničku praksu promicanja inovacija u Nizozemskoj. Ova se politika sastoji u unaprjeđenju suradnje između centara znanja (uključujući i sveučilišta) i poduzeća omogućavanjem smještanja poduzeća i start-upova u susjedstvu centara znanja te izdavanje potrebnih dozvola i, ako je to nužno, određenih potpora. Takva se politika pokazala iznimno uspješnom. No, čini se da je razvijanje politika obrazovanja za sve sektore ekonomije puno teže. Kada poslodavci i radnici imaju suprotne interese to postaje još teže, posebice ako se poslodavci boje da bi ih radnik koji je stekao neko obrazovanje mogao napustiti ubrzo nakon stjecanja novih kvalifikacija ili ako radnik mora poslodavcu platiti troškove obrazovanja. Zbog toga stvaranje fondova za obrazovanje koje bi mogli koristiti svi poslodavci i radnici, koji se žele prekvalificirati za obavljanje drugih poslova, može pridonijeti rastu vještina.

Ključne riječi: inovacije; Nizozemska; politika obrazovanja; rast vještina; radnici.

\section{Zusammenfassung}

\section{STÄRKUNG DER KOMPETENZEN UND INNOVATION IN DEN NIEDERLANDEN}

Dieser Beitrag beschreibt ein Beispiel für bewährte Verfahren in den Niederlanden bezüglich der Förderung der Innovation von Unternehmen. Diesbezüglich fördert die niederländische Politik die Zusammenarbeit zwischen Wissenszentren (einschließlich der Universitäten) und Unternehmen, ermöglicht, dass die Unternehmen und Startups in der Nähe von Wissenszentren ihren Sitz haben, hilft bei der Erhaltung von Genehmigungen, und, falls erforderlich, gewährt Zuschüsse. Solche Politik hat sich als erfolgreich erwiesen. Die Entwicklung der Politik der beruflichen Bildung für alle Wirtschaftssektoren ist andererseits schwieriger zu erreichen. Dies kann noch schwieriger werden, falls Arbeitgeber und Arbeitnehmer gegensätzliche Interessen haben, insbesondere falls Arbeitgeber Angst davor haben, dass der neulich ausgebildete Arbeitnehmer nach der Erhaltung seiner Qualifikation seinen Arbeitsvertrag kündigen

* Dr. sc. Frans Penning, redoviti profesor, Pravni fakultet, Sveučilište u Utrechtu, Nizozemska; f.pennings@uu.nl 
wird, oder falls der Arbeitnehmer den Zuschuss erstatten muss. Deshalb kann die Gründung von Ausbildungsfonds, welche sowohl für Arbeitgeber als auch für Arbeitnehmer, welche die Qualifikation für eine neue Stelle suchen, der Stärkung von Kompetenzen beitragen.

Schlüsselwörter: Innovationen; die Niederlande; Ausbildungspolitik; Stärkung von Kompetenzen; Arbeitnehmer.

Riassunto

\section{L'INCENTIVO ALL'INCREMENTO DI COMPETENZE ED INNOVAZIONE NEI PAESI BASSI}

Il presente lavoro illustra la best practice nei Paesi Bassi con riferimento alla promozione dell'innovazione imprenditoriale. Tale politica riguarda la promozione della cooperazione tra i centri del sapere (incluse le università) e le imprese, cercando di situare le imprese e le start-up nelle vicinanze dei centri del sapere, assistendoli nelle attività volte all'ottenimento dei permessi richiesti e, ove necessario, con sovvenzioni. Tale politica risulta raccogliere molti successi. Lo sviluppo di una politica di formazione per tutti i settori dell'economia, d'altra parte appare più difficile. Ciò diviene ancora più complesso se i lavoratori ed i datori di lavoro hanno interessi contrapposti; in particolare, se i datori di lavoro temono che il lavoratore così formato possa poi lasciare il lavoro dopo avere acquisito nuove qualifiche oppure se il lavoratore debba rimborsare la sovvenzione. Pertanto, l'istituzione di fondi per la formazione, accessibile a tutti i datori di lavoro ed ai lavoratori, che vogliano qualificarsi per un altro impiego, può contribuire all'incremento di competenze.

Parole chiave: innovazione; Paesi Bassi; politica di formazione; incremento di competenze; lavoratori. 
